\title{
MODERNIDADE PARA QUEM?: O NEGRO E A URBE PAULISTANA
}

\author{
MODERNITY FOR WHOM?: THE BLACK PEOPLE AND THE \\ PAULISTANA URBE.
}

DOI: http://dx.doi.org/10.15448/2178-3748.2018.1.23987

\author{
Sheila Alice Gomes da Silva \\ Doutoranda em História - PUCSP \\ sheilagomessilva1@gmail.com \\ Felipe Eugênio de Leão Esteves \\ Doutorando em História - UFBA \\ lipeesteves@hotmail.com
}

\begin{abstract}
RESUMO: O presente artigo estabelece uma contextualização a partir dos processos migratórios do campo para o território urbano, tomando a cidade de São Paulo entre finais do século XIX e o início do século XX como fonte, especificamente sua relação com os grupos negros e imigrantes, sobretudo italianos, para refletir sobre os processos de urbanização da cidade. Pautados numa modernidade elitista e de caráter eurocêntrica, impressa - na segunda metade do século XIX e nas primeiras décadas do século XX - nos territórios centrais da urbe, leva-nos a identificar consequências sobre a presença dos grupos negros que habitavam as respectivas regiões. Em nome de um projeto civilizatório baseado na projeção europeia de embelezamento e de progresso, levado à frente por uma incipiente burguesia urbana, ações higiênicas de extrema violência expulsaram e segregaram tais populações. Logo, pergunta-se: modernidade para quem? Mais do que uma cidade buscando um pseudodesenvolvimento, seu ideal era branco, europeu, não havia espaços para os negros. A modernidade buscada se fez seletiva e discriminatória, em um movimento materializado no tecido urbano que destacou privilégios de uns à custa da invisibilidade de outros.
\end{abstract}

PALAVRAS-CHAVE: Modernidade. Cidade de São Paulo. Grupos negros e urbanização.

ABSTRACT: This paper establishes a context from the migration field processes for urban territory, with the black groups actors and immigrants, especially Italians to reflect on the processes of urbanization in São Paulo. Guided by an elitist and Eurocentric modernity character, printed - in the second half of the nineteenth century and the first decades of the twentieth century - in the central areas of the metropolis, it leads us to identify consequences of the presence of black groups inhabiting their regions. On behalf of a civilizational project based on the European projection beautification and progress, carried forward by an incipient urban bourgeoisie, hygienic actions of extreme violence and expelled segregate such populations. So we ask: Modernity for whom? More than a city seeking a pseudo development, his ideal was white, European, there was space for blacks. The sought modernity became selective and discriminatory, a materialized movement in the urban fabric that highlighted a privilege at the expense of others invisibility.

KEYWORDS: Modernity. City of São Paulo. Black groups and urbanization.

\section{INTRODUÇÃO}

A frase em latim Non ducor, duco, que significa "Não sou conduzido, conduzo", encontra-se transcrita no brasão oficial da cidade de São Paulo, popularmente conhecida como o centro financeiro e cultural do Brasil, megalópole, cidade do mundo, e comunica a pretensa 
condição de soberania e hegemonia que esta cidade atribui a si mesma. Apesar disso, esta é uma metrópole de diversas realidades. Um cenário de contradição, cerzido por um progresso desvairado e imprevidente.

Há uma complexidade no tecido urbano paulistano que deixa revelar uma modernidade produtora de antagonismos territoriais, sociais e demográficos. Uma lógica que definiu arbitrariamente oprimidos e opressores e produziu desigualdades. O desenvolvimento da metrópole, na perspectiva das condições de vida de seus respectivos habitantes, faz saltar desníveis e distâncias entre as populações urbanas, evidenciando um contraste entre acumulação e pobreza. Autores como Raquel Rolnik (2001), Carlos José Santos (2003), Antônio Risério (2012), José Geraldo Vinci de Moraes (1997) e Amailton Azevedo (2006) lançaram luzes sobre a historiografia produzida para pensar a urbe paulistana para além de seus chavões, contribuindo preponderantemente para as reflexões sobre as conjunturas, os aspectos materiais e humanos que conduziram as manobras de desocupação do território discutidas neste trabalho.

Contudo, faz-se necessário pontuar que o conceito que suscitamos sobre modernidade baseia-se na baliza ideológica e discursiva atrelada ao tempo euro-ocidental de desenvolvimento material e de concepção moral. Orientamo-nos pelo que trouxe Stuart Hall quando compreende a modernidade no ocidente como um ato perene do colonizador em progredir com o apagamento étnico, respaldado no nacionalismo pseudo-homogeneizador de identidades, dado sua representatividade política seletiva. Hall trata a modernidade ocidental dentro dos projetos de construção da ideia homogeneizadora de Estado-nação como carregada da necessidade de erradicar a diferença, seja por meio da assimilação, seja pela abstração dessa realidade material (HALL, 2014). Isso dialoga vividamente com o que traz Paul Gilroy (2007) a respeito da modernidade como processo de duas faces: a completa inclusão de valores e de populações em dadas formas de vida e a inesgotável exclusão do que se diferencia desse formato. "A maioria das nações modernas consiste em culturas separadas que só foram unificadas por um longo processo de conquista violenta - isto é, pela supressão forçada da diferença cultural" (HALL, 2014, p.16) . O pensamento de Hall converge para o de Gilroy quando este considera que o conceito de modernidade engloba "indagações sobre a conexão entre racionalidade e a irracionalidade ao dirigir atenção para os laços entre as tipologias raciais e a herança do iluminismo" (GILROY, 2007, p. 78).

Com isso, aproximamo-nos de nossa abordagem presente no título, quando questionamos "modernidade para quem?" no processo de crescimento e reordenação urbana em São Paulo. Essas dinâmicas urbanas evidenciaram ações ancoradas em um projeto de 
modernidade elitista e de influência eurocêntrica que "[...] implicou em segregação socioespacial. Intervenção pública seletiva e discriminatória no espaço urbano, privilegiando os privilegiados" (RISÉRIO, 2012, p. 210). Esse projeto foi colocado em prática por manobras expropriatórias de extrema violência a partir de meados do século XIX, e, desde então, passou a marcar a distribuição espacial das populações em intersecção com a condição social dos habitantes. O modo de ser e estar dos grupos negros não compatibilizava com a ideia de futuro da cidade, portanto, eles foram excluídos da prometida modernidade e empurrados para espaços periféricos, de modo a torná-los invisíveis. Isso conformou uma exclusão racial e justificada pela razão ocidental. A cidade foi sendo repovoada a partir dos fluxos migratórios e imigratórios europeus, além de todo o desenvolvimento agrícola e industrial que foi estabelecendo suas características cosmopolitas.

Sem perder de vista grupos negros, que se tornaram a força de trabalho protagonista na cafeicultura paulista, mas que também trilhou caminhos urbanos e resistiu às violentas opressões de uma elite que os queria unicamente para a servidão, evidenciamos uma São Paulo que se constituiu enquanto campo de tensões sociais e raciais. Uma cidade que perseguiu um ideal nacional de identidade, com o branco no passeio diário, nos cafés à la Belle Époque, nos cargos públicos, nas universidades, e o negro escondido - isolado, ou muito bem trajado, com uma bandeja à mão e cabisbaixo, mantendo sua subalternidade em uma sociedade pós-escravagista.

\section{O NEGRO, O IMIGRANTE E A EXPLORAÇÃO DO TRABALHO}

O desenvolvimento da produção cafeeira em meados do século XIX, no Sudeste, impulsionou a cidade de São Paulo para uma reestruturação urbanística que, segundo Moraes (1997), vai transformar um simples entreposto comercial em uma metrópole de muitas faces. "A posição econômica da cidade se transformou totalmente com a expansão do cultivo do café na então província [...]" (ROLNIK, 2001, p. 15). Essa expansão agrícola também conjugou a construção de redes ferroviárias, o que proporcionou conexões com outras regiões, alargou fronteiras comerciais e conquistou maiores mercados consumidores. A implantação das estradas de ferro significava, para a região, enquadrar-se nos padrões das cidades tidas por civilizadas. Ademais, significou para a cidade de São Paulo rearranjos espaciais, expandindose seus limites para além do núcleo central, constituindo alargamentos do meio urbano.

Com um clima propício e com os férteis solos da região do oeste paulista, especificamente os do Vale do Paraíba e de outras regiões do nordeste paulistano, esses 
grandes territórios produtores conseguiam atender a um mercado consumidor crescente apoiando-se na mão de obra negra escravizada. Com o fim do tráfico internacional de negros, os senhores cafezistas passaram a comprar escravos de outros locais, como os estados de Minas Gerais e do Rio de Janeiro e das regiões Norte e Nordeste. Isso promoveu um enegrecimento em massa da demografia paulistana: “[...] em 1870, dos 32 mil habitantes de São Paulo, um terço era negro ou mulato" (ROLNIK, 2001, p. 15).

Mesmo contando com essa massa trabalhadora trazida pelo tráfico interno, o sistema escravocrata, no Brasil como um todo, estava ruindo. As fugas e rebeliões coletivas dos negros das fazendas, como as citadas por Andrews (1998), obrigavam os fazendeiros a renderem-se à abolição: "Durante o último ano de existência da escravidão, 40 mil escravos foram libertados por seus senhores nas regiões cafeeiras do centro e do oeste de São Paulo, mais de 1/3 da população escrava total do Estado" (ANDREWS, 1998, p. 73). Em uma sociedade que tinha como base o trabalho escravo, quando a "[...] história do trabalho é, sobretudo, a história do escravo" sendo "[...] ele o grande instrumento de trabalho" (COSTA, 2010, p. 14), cabia a estes as tarefas fundamentais que regiam todo o funcionamento de uma fazenda de café. Segundo Martins (2014), abolir a escravidão significaria a falência iminente da economia cafeeira paulista, o que fez dos cafezistas "uma classe profundamente desgostosa com a abolição, que golpeou a fundo seus interesses" (MOURA, 2014, p. 21). O negro escravizado era, portanto, "a grande riqueza das fazendas de café" ( MOURA, 2014, p. 24).

Após a promulgação da abolição, os negros não aceitavam qualquer trabalho que os aproximasse novamente do sistema escravocrata, recebendo rações diárias e trabalho sem remuneração, por exemplo (ANDREWS, 1998). A liberdade significava, necessariamente, a distância daquilo que o trabalho representava para os ex-escravizados: o tronco, os suplícios, os estupros, a desumanização, entre outras barbáries. O terror indizível da escravidão corrompeu o sentido do trabalho, transformando-o de um elemento colaborativo na luta pela sobrevivência do homem para o resultado da opressão e da exploração.

O recebimento de salário faria do ex-escravizado um trabalhador com poder de compra, um indivíduo que poderia se inserir na sociedade civilizada, tornando-se, assim, um cidadão. Ao negro, porém, não estava destinada qualquer aceitação de sua nova condição. A abolição, mesmo antes de ser decretada, contou com um rearranjo prévio das elites e do governo, que, de antemão, já se preparavam para as mudanças: “[...] a partir de 1869, nas Assembleias Legislativas de todo o país, começaram a ocorrer acalorados discursos que exaltavam a mão de obra europeia como ideal para substituir o trabalhador escravo e liberto" (BENTO, 2006, p. 30). Esse processo serviria para ajudar no processo civilizatório do país, 
pela visão embranquecedora, apurando as raças. Além disso, em "1871 e 1872 a Assembleia de São Paulo reservou fundos para subvencionar os custos dos fazendeiros que desejavam trazer imigrantes da Europa para trabalhar em suas fazendas" (ANDREWS, 1998, p. 97). Os novos trabalhadores do Brasil sem escravidão, portanto, seriam brancos, o que prova que a integração do liberto ou emancipado no mundo do trabalho, assim como na sociedade brasileira, como homem livre/cidadão, não era prioridade. O mundo do trabalho, na sociedade brasileira, tem no racismo seu elemento decisivo, já que a cor tornou-se um requisito.

Mesmo com toda experiência disciplinadora adquirida na escravidão, principalmente na lavoura, constituiu-se toda uma conjuntura histórica que classificava os negros como incapazes de colaborar ou serem úteis para as novas relações de trabalho livre que se estabeleciam no Brasil. O homem negro era sempre representado como:

[...] apático para o trabalho livre e acostumado à coação de um sistema irracional de produção, não pode fazer frente à concorrência representada pelo imigrante europeu, trabalhador este já afeito a uma atividade disciplinada, contrato de compra e venda e força de trabalho (AZEVEDO, 1987, p. 21).

Emília Viotti da Costa (1999), tratando da urbanização no Brasil no século XIX, afirma que, pouco antes de 1870, a elite escravocrata, envolvida na dinâmica de importação e exportação, adotou um liberalismo que atendia aos seus interesses escravistas: "Purgando o liberalismo de seus aspectos radicais adotaram um liberalismo conservador que admitia a escravidão e conciliaram liberalismo e escravidão da mesma forma que seus avós haviam conciliado a escravidão com o cristianismo" (COSTA, 1999, p. 359) A partir de 1885, o panorama, no entanto, mudou: "Os fazendeiros das áreas em expansão haviam encontrado a resposta na imigração. Provavelmente, não teriam procurado alternativas para o trabalho escravo se não estivessem ante múltiplas pressões. Além disso, se tivessem mais confiança nas possibilidades de sobrevivência da escravidão ou não tivessem encontrado alternativas, teriam lutado para manter a instituição" (COSTA, 1999, p. 362).

Com a desarticulação progressiva do sistema escravocrata, havia uma nova massa de trabalhadores desejada pela elite nacional: os imigrantes europeus. Tratou-se de manobra estratégica do governo brasileiro para europeizar, embranquecer e apagar a presença negra da sociedade brasileira, conforme salienta Santos (2003), já que os fazendeiros não precisariam de novos trabalhadores se optassem por recontratar os grupos de ex-escravizados/livres. Segundo Martins (2012), os cafeicultores desejavam retomar o controle sobre a força de trabalho alterada pela revolução da abolição - como intitulada pelo autor - e, dessa forma, 
constituiu-se um discurso que excluiu a força de trabalho do negro, apontando para o trabalhador ideal de um novo Brasil, uma nação priorizando o progresso, rumo ao desenvolvimento. Não havia nenhum outro interesse, o Brasil desejava os europeus:

A constituição de 1891 proibiu especificamente a imigração africana e asiática para o país, e os governos nacionais e estaduais transformaram a atração da imigração europeia para o Brasil em uma prioridade do desenvolvimento nacional (ANDREWS, 1998, p. 91).

Consoante Munanga (2008), uma súbita equiparação legal entre negros e brancos não garantiu, definitivamente, igualdade de direitos e oportunidades aos grupos negros. Mesmo em um Brasil sem escravidão, manteve-se uma etiqueta, uma praxe escravocrata que buscava subordinar e controlar uma população que já possuía algum direito civil, mas sofria com a imponência de uma ideologia do branqueamento, que tenciona as categorias de cor e de certa maneira configura um processo de racialização nas cidades, no universo urbano.

Os imigrantes recém-chegados ao Brasil contavam com empregadores ávidos pela presença europeia, acreditando em um suposto sentido civilizatório e na cura para uma terra enegrecida, valorando a permanência das dinâmicas coloniais, conforme discute Santos (2003). Pairava no imaginário da classe dominante uma Europa que assumia a representação de uma elite nacional forte, o desenvolvimento, o progresso, o luxo e as riquezas.

A cidade de São Paulo, especificamente, foi o local que mais recebeu imigrantes europeus no país, sendo, por vezes, chamada de "cidade de desenraizados" por empreender programas estatais que subsidiavam a vinda destes, como citam Martins (2012) e Moraes (1997). Alguns elementos faziam parte desse suporte, como: passagens, estadia, alimentação, documentação, entre outros. Podemos observar, consoante Martins (2012) que:

O Estado de São Paulo seria o mais bem-sucedido na tarefa liderada pelos cafeicultores de atrair a mão de obra imigrante, pois entre 1887 e 1900 entraram no estado 599.426 pessoas, que vinham principalmente da Europa. A cidade de São Paulo cresceu 3\% entre 1872 e 1886, 8\% entre 1886 e 1890 e $14 \%$ entre 1890 e 1900 . O processo imigratório era tão intenso que em1920, a maioria absoluta da população da cidade de São Paulo era italiana. (Ibidem, p. 26).

E Rolnik (2001), por sua vez, declara que:

O primeiro grande grupo estrangeiro a chegar, em fins do século 19 , foi italiano: entre 1888 e 1900 passaram por São Paulo quase 900 mil imigrantes, dos quais 70\% eram provenientes da Itália. [...] Entre 1908 e 1930 se instalaram em São Paulo cerca de 50 mil sírios e libaneses e 35 mil judeus, oriundos principalmente da Europa-oriental no pós-guerra, que se somaram a um grande número de europeus. (Rolnik, 2001, p.16). 
De acordo com Andrews (1998, p. 97), no ano de 1884 o governo "reservou 400.000 mil réis para pagar os custos de viagem dos imigrantes que queriam se empregar na agricultura", criou campanhas que promoviam o Brasil e sua crescente demanda de trabalhadores, além de incentivar a Sociedade Promotora da Imigração, instituição privada que promovia a imigração com o foco de atrair europeus para as fazendas de café paulistas, entre 1884 e 1895 . Mesmo antes disso, no ano de 1850, foi outorgada a Lei de Terras, que, conforme Rolnik (1997), autorizou o governo a trazer colonos europeus para serem empregados em atividades agrícolas ou em trabalhos ligados à administração pública às custas do Tesouro Nacional. Com toda essa mobilização e esse incentivo, a população estrangeira já representava "a maioria da população de São Paulo - 55\% dos moradores da cidade em 1893" (Ibidem, p. 19). A força de trabalho imigrante auxiliou para que se expandisse extraordinariamente a cafeicultura e toda sua força econômica no país.

No entanto, o dinâmico ritmo de trabalho, a disciplina e a cobrança de altas taxas para que os novos trabalhadores pudessem sobreviver dentro das fazendas foi provocando um descontentamento nos imigrantes. Cabe salientar que a proposição de altas taxas como instrumento de regulação do trabalho não foi uma exceção destinada aos imigrantes: a greve negra de 1857, ocorrida em Salvador e narrada por Reis (1993), ilustra essa prática recorrente de exploração e é um exemplo da consciência política e econômica que permeava os trabalhadores negros de rua, escravizados ou libertos, sobre a importância de seus trabalhos para o funcionamento das cidades comerciais.

Em um enfrentamento da ordem imposta, os trabalhadores negros compuseram um forte e organizado movimento grevista, que parou o fluxo comercial da cidade por mais de uma semana, contra a instituição do pagamento de altas taxas para o trabalho nas ruas, o que objetivava declaradamente disciplinar e obter um maior controle sobre a presença negra no espaço público, porém onerava os rendimentos e acabava por impedir os não pagantes de realizarem seus trabalhos. Para os imigrantes, esses pagamentos significavam um endividamento tão grande que, segundo Andrews (1998), muitos não ganhavam nada com o trabalho. Assim como os negros de Salvador que se organizaram contra a exploração, os europeus, nas fazendas de café, também passaram a organizar paralisações e rebeliões em prol de melhores condições de trabalho e, em contrapartida, os fazendeiros passaram a enxergá-los com menos entusiasmo.

Além dos descontentamentos que estremeciam as relações de trabalho entre imigrantes e fazendeiros, o próprio café, nos primeiros anos do século $\mathrm{XX}$, enfrentou uma grande crise 
que abalou, principalmente, o valor de compra. Com relações de trabalho desgastadas e o reverberar da crise cafeeira, muitos trabalhadores imigrantes passaram a engrossar os movimentos de deslocamento em massa para os espaços urbanos, em busca de trabalho e de melhores condições de vida.

\section{A CISÃO DA URBE}

A cidade de São Paulo passou a receber uma grande massa migrante/imigrante das regiões rurais, além dos negros libertos, outrora escravos domésticos ou de ganho que, de acordo com Rolnik (1997), misturavam-se diariamente à dinâmica da cidade por intermédio de seus ofícios ou por aqueles que também estavam se fixando e oferecendo sua força de trabalho, o que vai promover um crescimento demográfico frenético.

Grande parte dos escravos libertos, especialmente nas regiões que apresentavam declínio da cultura do café, no Vale do Paraíba, tomaram o rumo das cidades e aí ofereceram sua força de trabalho, agora livre, concorrendo em desigualdade de condições com os brancos pobres e os imigrantes que aqui chegavam (MARICATO, 1997, p. 19).

Assim como os cafeicultores evidenciavam sua preferência étnica para o trabalho assalariado, a indústria e o centro urbano vão, também, reafirmar um caráter excludente nas relações trabalhistas do Estado brasileiro, renunciando aos negros. Martins (2012, p. 24) destaca as disputas que aconteciam entre estrangeiros e nacionais e que corporificavam as tensões étnicas, comuns na chamada cidade moderna: "Os imigrantes disputavam espaço com milhares de ex-escravos e pessoas pobres que improvisavam estratégias de sobrevivências nas franjas sociais". Mesmo livres, os negros não experimentaram uma igualdade de direitos e de oportunidades. O mercado de trabalho paulistano procurava, especificamente, trabalhadores brancos, o que favoreceu a integração dos imigrantes na formalidade, em detrimento de grupos negros relegados à informalidade em funções inferiorizadas.

O centro urbano da cidade passou a se industrializar de maneira crescente, principalmente com os investimentos dos cafeicultores que desejavam expandir seus negócios, como aponta Mattos (1958), e enxergavam na automatização da produção agrícola uma diminuição da necessidade de mão de obra, que sofria com a escassez nas fazendas. A indústria era vista como fornecedora de insumos para o campo e recebia muitos investimentos provenientes das fortunas cafeeiras, que, por sua vez, passavam a enxergar a necessidade de manter relações mais próximas com a cidade. A elite passou, assim, a se estabelecer em residências urbanas, verdadeiros palacetes, extensão de suas propriedades rurais que reluziam 
a magnitude do poderio e da riqueza provenientes do café. Moraes (2000) vai apontar, entre outros elementos, que esse período foi de um desenvolvimento urbanístico impulsionador de um processo de redefinição dos espaços sociais e urbanos, aliado ao desenvolvimento industrial que, consoante Mattos (1958), vai dar força a uma nova paisagem. A cidade foi crescendo em múltiplas direções.

A construção civil começa a apresentar um crescimento nunca visto em cidades brasileiras. Os prédios passavam a ter um perfil marcadamente urbano. O sistema comercial também foi se tornando mais eficiente e mais amplo, à medida que se estendiam os cabos submarinos, se fundavam casas importadoras e se ampliavam as operações bancárias. Certas trocas, que muitas vezes foram praticadas por escravos de ganho e forros, pelas ruas, transformaram-se. Abriram-se lojas de tecidos, confeitarias, mercearias e restaurantes (BERNARDO, 1998, p. 22).

A cidade de São Paulo foi urbanizada de forma frenética, passando por cima das heterogeneidades culturais e da situação material de extrema pobreza à qual era submetida grande parte da população, sobretudo a negra. Os grupos das elites intelectuais e políticas pensaram seus espaços como um território que precisava ser modernizado, em uma perspectiva europeia, e impulsionaram uma mudança radical de suas identidades. Com o suporte da hiperlegalização das ciências médicas, o que levava a cabo projetos eugênicos e higiênicos nos arredores urbanos, passou-se a idealizar um planejamento urbano que estipulava uma nova ordem: a cidade moderna.

A procura pela remodelação arquitetônica de São Paulo esteve relacionada à formulação de uma nova percepção do que deveria ser a cidade de São Paulo e seus lugares, à tentativa de eliminação de tradições inconvenientes e à marginalização dos indesejáveis (SANTOS, 2003, p. 126).

Esse grande projeto não incluía os grupos negros em sua estrutura e espacialidade e, por isso, os imigrantes europeus eram bem-vindos como antídoto da miscigenação, pois a idealização raciológica concebia nesses imigrantes europeus a saída que levaria ao branqueamento do território paulista. Segundo Rolnik (1989), “A face urbana desse processo é uma espécie de projeto de limpeza da cidade, baseado na construção de um modelo urbanístico" (Ibidem, p.6). Os espaços que eram predominantemente negros passavam a ser ocupados pelos europeus, em um movimento que, na verdade, deu corpo à "segregação urbana" marcada "por uma espécie de zoneamento social" (Ibidem, p. 6).

A cidade moderna consolidou o racismo, no entendimento de que as sociabilidades negras urbanas representavam um elemento crítico que precisava ser esfacelado e, por isso, foi acentuado e intensificado um processo segregacionista em linhas cartesianas, em uma 
disciplina espacial que delegou o lugar de cada indivíduo ou população dentro do território e na sociedade. A presença negra nas regiões centralizadas da cidade representava a não civilização: “[...] a população que ocupava o chamado Centro Velho de São Paulo acabou por ser desalojada pelos chamados trabalhos de melhoramentos da capital" (ROLNIK, 1989, p. 8). O chamado embelezamento não se encerrava na materialidade urbana ou em sua arquitetura, mas compreendia um embranquecimento cultural. Tratou-se de trato de uma limpeza étnica da região que buscava ser o grande polo de prestigio e poder do Estado. Os modos de vida das populações negras incomodavam e não se adequavam ao ideário de modernidade que se almejava.

As ações investidas em prol dos chamados melhoramentos da capital apontavam para um espaço territorial ordenado e destinado aos grupos da elite econômica, constituindo uma nova forma de entender a cidade, que, desde 1850, com a Lei de Terras, passou a monetarizar os espaços, fazendo-os alcançar status de mercadoria. Para ser dono era necessário efetivamente comprar, o que alterava profundamente o acesso sobre a terra caracterizado pelo ocupar e/ou tomar para si. A relação com a terra passava a ser estritamente comercial, tratavase de "uma nova regra do jogo de apropriação do espaço geográfico da cidade" (ROLNIK, 1997, p.16).

Os pobres nacionais e, nesse caso, os grupos negros - obstáculo ao projeto civilizacional - eram os alvos de um processo de expulsão dos lugares que se valorizavam na região metropolitana. Esse processo se deu de maneira truculenta, pela força ou por conta de custos que, elevados, forçavam o deslocamento ou a desterritorialização destes para outras áreas à margem do centro. Essas ações foram comumente chamadas por uma historiografia hegemônica de melhoramentos urbanos. Portanto, esses grupos eram percebidos pela sociedade como elementos impeditivos ao progresso e à moral pública, composta por valores que repeliam e/ou negavam as culturas negras, incentivando o individualismo e o isolamento, conforme evidencia Mattos (2008). Os negros representavam, para o almejado progresso e a futura metrópole, a força de trabalho, e não aqueles que poderiam e deveriam usufruir da atmosfera urbana que se constituía.

As elites paulistas eram as interlocutoras do grande movimento de redefinição territorial que a cidade de São Paulo estava mergulhada nas primeiras décadas do século XX. Tratava-se de um processo amplo que abarcava todos os espaços que compunham o cenário da urbe, como as estruturas das casas, as propriedades e, também, as ruas. As atas da Câmara Municipal e também a imprensa desse período evidenciam uma sociedade que se lança a regular e a disciplinar, inclusive, um espaço que, segundo Rolnik (2001), representava os 
grupos negros: as ruas. Isso significa que, além de propalar uma exclusão do negro no mercado de trabalho, regular o uso das ruas era outra maneira de combater esses grupos, que tinham no centro urbano uma oportunidade de ganhar seu sustento. Tais espaços representavam, para as elites, uma desordem frente ao necessário trânsito nas vias urbanas da tão desejada cidade moderna. Todo esse domínio que os grupos negros tinham sobre os espaços urbanos suscitava medo de possíveis levantes, provavelmente incontroláveis pelas autoridades.

Quitandeiras, lavadeiras, carregadores, entre outros trabalhadores negros livres, ou mesmo durante a escravidão, tinham para com as ruas múltiplos usos. Elas representavam "o lugar da escravaria, e também da libertinagem e devassidão, imediatamente identificada com quem ali permanecesse" (ROLNIK, 1997, p. 34). Além disso, configuraram-se como um lugar que exerceu um papel central na socialização e na construção da autonomia e da solidariedade entre os negros. As ruas pertenciam aos negros, eram os territórios vivos das diásporas urbanas. A insistente presença negra nas ruas é "um sinal de que nem tudo pode ser controlado" (AZEVEDO, 2006, p. 177).

Araújo et al. (2006, p. 76), debruçado sobre a temática das cidades negras, narra uma cena cotidiana dos grandes centros em que os negros eram protagonistas: "Todas as manhãs, quando o sol pouco apontava no horizonte, uma imensa legião de escravos se encaminhava para os chafarizes [...] Iam buscar água para as casas de seus senhores, já que ali não havia encanamento doméstico". Era nas ruas que os escravizados encontravam uma maior possibilidade de se deslocar, ter contato com vários tipos, tecer relações, e, muitas repetidas vezes, subverter a ordem. Mesmo assim, é importante salientar que esta mobilidade física não representou maior relaxamento na rotina dos escravizados de ganho que nas ruas desempenhavam seus trabalhos.

Diante desse domínio étnico que se podia perceber das ruas do centro da urbe, as primeiras funções do conjunto de leis urbanísticas sistematizadas, nos últimos anos do século XIX, objetivavam especificamente limpar, delimitar e redefinir os espaços públicos. O código de Posturas da Câmara Municipal da Imperial Cidade de São Paulo, criado em 1875 - revisto e ampliado em 1886 -, conforme cita Rolnik (1997), apontava para a reorganização das posturas vigentes, propondo uma demarcação legal de espaços como as moradias operárias, cortiços e cubículos onde, com "o saneamento e a higiene precários - não havia rede de esgoto ou água canalizada e tratada -, dejetos eram jogados em terrenos baldios e rios" (ARAÚJO et al., 2006, p. 21). 
No ano de 1894, o governo estadual criou o Código Sanitário e uma Diretoria de Higiene, as quais exerciam um papel policialesco de inspeção e controle. As ações públicas, na prática, atribuíam às populações miseráveis a culpa pelo descontrole sanitário no universo urbano de São Paulo. Rolnik (1997), ao analisar pareceres de eminentes médicos e engenheiros fornecidos ao Conselho Superior de Saúde Pública do estado do Rio de Janeiro referente ao ano de 1886 , percebe relatos que descrevem tais populações moradoras das casas coletivas como portadoras de um baixo nível psicológico e moral, o que vai evidenciar uma mentalidade racista que subsidiava as ações do poder público, de maneira geral, e dava força para a realização de ações extremamente violentas no esvaziamento do centro da cidade, promovendo expropriação e segregando as populações pobres.

O discurso que evidenciava a necessidade "de um cenário limpo e ordenado que correspondia à respeitabilidade burguesa com a qual a elite do café se identificava" (ROLNIK, 1997, p. 37), a proibição dessas estruturas de moradia deixou evidente sua intencionalidade, que em nada flertava com a de estética ou higiene, mas antes "[...] tentavase apagar o que havia de registros africanos nesses modos de viver na cidade" (AZEVEDO, 2006, p. 192). Era o banimento de um modo de viver e de uma cultura que impregnava o centro da urbe, era a reafirmação de velhos papéis sociais outrora estabelecidos pelo sistema escravocrata e perpetuados pela sociedade cafeeira. Ademais, debates sanitaristas internacionais apontavam os inchaços demográficos das grandes cidades como um dos elementos responsáveis pelo alastramento das doenças epidêmicas. A presença negra maciça era mais uma vez percebida como uma ameaça à civilização idealizada, aquilo que corrompia e tornava suja a cidade.

O combate às pragas se constituía como uma missão para as ações do projeto urbanístico municipal, que se dava pela expropriação de grupos negros e pobres dos territórios majoritariamente ocupados por eles, como as residências coletivas, o que diluía a resistência negra sustentada pela solidariedade nesses espaços. Os "Planos de Melhoramentos da Capital" incumbiu à prática da fiscalização ou da repressão nesses espaços de moradia coletiva, sob a égide de que aquele modo comunitário de vida que se permitia realizar as atividades cotidianas representavam uma facilidade para a proliferação de males.

[...] tinha uma arquitetura que implicava um cotidiano em que, na maior parte do tempo, as atividades relacionadas com o morar aconteciam em um espaço semipúblico, intermediário entre o interior da casa e a rua - os pátios e quintais coletivos. Os quartos eram usados praticamente para dormir e guardar os "trastes". Cozinhar, relaxar, conversar, brincar com as crianças, 
lavar pratos eram atividades desenvolvidas nos quintais (ROLNIK, 1997, p. $66)$.

A urbe se formava nos moldes europeus (brancos), projetando uma espécie de modernidade abstrata, incongruente e restrita, conjugada na introdução de uma visão de relação do mercado imobiliário nascido da livre associação entre higienização e capitalismo, entendendo que os cortiços e as habitações comunitárias ocupadas por sujeitos indesejáveis poderiam ter maior valoração comercial. Por meio da violência do poder policial sanitário, grupos negros foram empurrados para bairros distantes do centro da cidade, carentes de infraestrutura e recursos de locomoção.

Ao mesmo tempo que a concentração de investimentos em "melhoramentos" e a legislação vai alinhando os territórios da riqueza, ela vai também delimitando aqueles onde deverá se instalar a pobreza. O movimento [...] é centrífugo [...] delimita as bordas da zona urbana ou mesmo a zona rural como local destinado para os mais pobres. [...] a lógica de destinar as lonjuras para os pobres atravessou, incólume, o século 20 (ROLNIK, 2001, p. 22).

Contudo, esperava-se não somente afastá-los, mas, necessariamente, apagar a presença negra dos lugares centrais da cidade junto com suas experiências, memórias e vivências. Desse modo, o processo de urbanização paulistano é revelador de um ideal de modernidade promotora da pobreza social, econômica, espacial e da divisão. Separando negros e pobres da elite demarcava-se mais do que um espaço geográfico, um território social. A segregação se constituiu como uma das bases de nossa estrutura urbana e territorial, de forma que a cidade de São Paulo foi se constituindo a partir de uma topografia ou geografia urbana que priorizou a reafirmação das hierarquias étnicas e sociais.

\section{CONCLUSÃO}

Na contramão de uma produção historiográfica dominante, vasta, extremamente popularizada e introjetada no imaginário coletivo, entendeu-se a importância de que novos pesquisadores se lancem em perceber e refletir sobre as ausências produzidas. Nessa perspectiva, procuramos denotar a participação ativa, especificamente, de atores ditos coadjuvantes ou invisibilizados no senso comum a partir do olhar atento para os primeiros passos dos processos de urbanização da cidade de São Paulo, o que nos fez reconhecê-la como lugar de enfrentamento.

Ostentando uma imagem de imponência e progresso, a urbe paulistana produziu, desde a segunda metade do século XIX e até hoje, desigualdades. Tais inconveniências, aos louros

Oficina do Historiador, Porto Alegre, EDIPUCRS, v. 11, n. 1, jan./jun. 2018, 
reservados às histórias que circundam o território, ficaram nas dobras de um processo de urbanização que se pautou, sobretudo, na exclusão daqueles que desarmonizavam a lógica proposta. Valendo-se de diversas artimanhas e em nome de um embelezamento e da modernidade, a burguesia urbana executou com extrema violência a expulsão e segregação dos grupos negros moradores da região central da cidade. A partir de um discurso justificado que aproveitava um momento oportuno, em que a opinião publica mundial se voltava para as péssimas condições da saúde pública e para a desenfreada proliferação das doenças nas metrópoles em construção, a imagem dos grupos negros foi racionalmente associada às mazelas, aos distúrbios, às patologias e aos problemas.

Baseada em um ideal eurocêntrico, a modernidade urbana não passou de um conglomerado de promessas não cumpridas para os grupos desprivilegiados. Fazendo-se seletiva e discriminatória, ela produziu uma relação de estranhamento entre os negros e a urbe paulistana. A redefinição dos espaços sociais e urbanos constituiu uma nova paisagem, uma cidade moderna que consolidou o racismo.

\section{REFERÊNCIAS}

ANDREWS, George Reid. Negros e brancos em São Paulo (1888 -1988). Bauru/SP: EDUCS, 1998.

ARAÚJO, Carlos Eduardo Moreira de et al. Cidades Negras: africanos, crioulos e espaços urbanos no Brasil escravista do século XIX. São Paulo: Alameda, 2006.

AZEVEDO, Amailton Magno. A memória musical de Geraldo Filme: os sambas e as microÁfricas em São Paulo. 2006. 242f. Tese (Doutorado em História) - Faculdade de História, Pontifícia Universidade Católica de São Paulo, São Paulo, 2006.

AZEVEDO, Célia Maria Marinho de. Onda negra, medo branco: o negro no imaginário das elites - século XIX. Rio de Janeiro: Paz e Terra, 1987.

BENTO, Maria Aparecida. Cidadania em Preto e Branco. São Paulo: Ática, 2006.

BERNARDO, Teresinha. Memória em branco e negro: olhares sobre São Paulo. São Paulo: EDUC - Fundação Editora da UNESP, 1998.

COSTA, Emília Viotti da. Da monarquia à república: momentos decisivos. 6. ed. São Paulo: Editora da UNESP, 1999.

. Da senzala à colônia. 5. ed. São Paulo: Editora UNESP, 2010.

GILROY, Paul. Entre Campos: nações, culturas e o fascínio da raça. São Paulo: Annablume, 2007. 
HALL, Stuart. Identidade cultural na pós-modernidade. Rio de Janeiro: Lamparina, 2014.

MARICATO, Ermínia. Habitação e cidade. São Paulo: Atual, 1997.

MARTINS, Ana Luiza. Café, trabalho e cotidiano no vale do Paraíba Paulista. In: MOURA, Carlos Eugênio Marcondes de (Org.). Fazendas de Café do Vale do Paraíba: o que os inventários revelam (1817-1915). São Paulo: Condephaat, 2014. p. 71-94.

MARTINS, Marcelo Thadeu Quintanilha. A Civilização do delegado: Modernidade, polícia e sociedade em São Paulo nas primeiras décadas da República, 1889-1930. 2012. 315 f. Tese Doutorado em História) - Faculdade de Filosofia, Letras e Ciências Humanas, Universidade de São Paulo, São Paulo, 2012.

MATTOS, Dirceu Lino de. O parque industrial paulistano. In: AZEVEDO, Aroldo (Org.). A cidade de São Paulo: estudos de geografia urbana. v. 3. São Paulo: Companhia Editora Nacional, 1958. p. 5-42.

MATTOS, Wilson Roberto de. Negros contra a ordem: astúcias, resistências e liberdades possíveis (Salvador, 1850-1888). Salvador: EDUNEB, EDUFBA, 2008.

MORAES, José Geraldo Vinci de. As sonoridades paulistanas: a música popular na cidade de São Paulo - final do século XIX ao início do século XX. Rio de Janeiro: Funarte, 1997. Metrópole em sinfonia: história, cultura e música popular na São Paulo dos anos 30. São Paulo: Estação Liberdade, 2000.

MOURA, Carlos Eugênio Marcondes de. Inventariando Inventários. In: (Org.).

Fazendas de Café do Vale do Paraíba: o que os inventários revelam (1817-1915). São Paulo: CONDEPHAAT, 2014. p. 17-28.

MUNANGA, Kabengele. Rediscutindo a mestiçagem no Brasil: identidade nacional versus identidade negra. 3. ed. Belo Horizonte: Autêntica, 2008.

REIS, João José. A greve negra de 1857 na Bahia. Revista USP, São Paulo, n. 18, p. 8-29, jun/jul/ago 1993.

RISÉRIO, Antônio. A cidade no Brasil. São Paulo: Editora 34, 2012.

ROLNIK, Raquel. São Paulo. São Paulo: Publifolha, 2001.

A cidade e a lei: legislação, política urbana e territórios na cidade de São Paulo. 3. ed. São Paulo: Studio Nobel/Fapesp, 1997.

Territórios negros nas cidades brasileiras (etnicidade e cidade em São Paulo e Rio de Janeiro). Revista de Estudos Afro-Asiáticos, Rio de Janeiro, n. 17, set. 1989. Disponível em: <http://www.usp.br/srhousing/rr/docs/territorios_negros_nas_cidades_brasileiras.pdf>. Acesso em: 10 nov. 2014. 
SANTOS, Carlos José Ferreira dos. Nem tudo era italiano: São Paulo e pobreza (1890-1915). São Paulo: Annablume/Fapesp, 2003.

ARTIGO ENVIADO EM: 12/05/2016 ARTIGO ACEITO PARA PUBLICAÇÃO EM: 17/08/2016 